\title{
The EU Commission's Digital Tax Proposals and its Cross-platform Impact in the EU and the OECD
}

Author: Wouter Lips - Draft 23/6/2019

\begin{abstract}
The EU Commission's directive proposals on corporate taxation of digital multinationals, especially the digital services tax (DST), show the increased assertiveness of the Commission on taxation matters. Both inward and outwards in the parallel OECD negotiations on digital taxation. By drawing on Kingdon's Multiple Streams Framework, elite interviews and policy documents, I assess the dynamics of the proposal at the EU and OECD. While the DST will fall short in the EU Council due to unanimity requirements, I argue that the Commission actually achieved its pre-prescribed goals. Within the EU, it provided coherency for unilateral DSTs by member states. At the OECD, the proposals increased the threat of uncoordinated unilateral measures. This created a period of uncertainty and pressured laggard states, which helped lead to a tentative window for reform. As such, the proposals are an example of cross-platform policy entrepreneurship by the EU Commission, projecting influence despite unanimity constraints.
\end{abstract}




\section{Introduction}

International principles for corporate taxation of multinationals have been subject to immense revision over the last 5 years as a result of the increased political salience of cross-border tax avoidance, and the vulnerability of the current tax rules to this phenomenon (Forstater \& Christensen, 2017). In 2015, the OECD finalized the Base Erosion and Profit-Shifting (BEPS) project: a 15-point action plan endorsed by the group of 20 (G20) with the underlying goal to re-align taxation with economic substance and value creation (OECD, 2015b).

The first action of BEPS is titled "Addressing The Challenges of the Digital Economy" (OECD, 2015a). Its first place symbolizes the pressing issue of taxing an increasingly digitalized economy. There have been prominent mediatized reports on the aggressive tax planning within large tech-driven firms. This scrutiny has led to a string of cases ranging from Google and Amazons' state aid rulings by the EU Commission, over Apple's hearing in the US senate and Seattle's bid for an 'Amazon Tax'. There is an increasing awareness that the historically agreed-upon principles for international taxation are unfit for a digitalized economy (European Commission, 2018c).

Yet, no agreement on the matter was reached and the report of action 1 resembles more an academic exercise (personal interview, 2018) that attempts to diagnose the BEPS-related problems of digital business models. The decision deadline on final recommendations was moved to 2020. An interim report, released in 2018, showed clear fault lines between three groups of countries: a group that feels the BEPS package dealt sufficiently with digital business models, a group that feels only targeted measures are needed and a group that feels the digitalization of the entire economy is so disrupting that the existing tax rules need revision (OECD, 2018b).

In response to the slow movement within the OECD, the EU Commission released its own plans less than a week after the OECD's interim report. The Commission unveiled two related directive proposals: (a) an interim tax of $3 \%$ on the revenue of certain digital transactions of companies generating more than $€ 750$ million revenue worldwide and 50 million in the EU, and (b) a long-term proposal for a significant digital presence as a ground for tax liability, amending the current requirement of a physical permanent establishment. This would incur tax liability if a company has, for example, a pre-determined number of users or volume of sales in an EU jurisdiction. These proposals clearly deviate from the scope of the BEPS project.

The Commission proposals are puzzling for multiple reasons. First, they can be interpreted as a challenge to the OECD's position as the foremost agency overseeing international tax rules coordination. The EU Commission is not attempting to replace the OECD as the global standard setter but has made clear that it is willing to take EU-only steps (personal interview, 2018). Second, the dominant narrative surrounding the proposals was that they were primarily aimed at United Statesbased companies. This risked both upsetting the tax negotiations at the OECD and distort already contentious EU-US economic relationships with spill-overs into trade policy and tariff discussions. Third, taxation matters in the EU require unanimity ${ }^{1}$ in the EU Council. It was entirely predictable that certain EU member states would oppose the proposals, as happened. Both on the grounds that a revenue tax is not a solid solution and that a regional EU solution is less preferable than a multilateral OECD solution (Reuters, 2018). The proposals' chances of implementation were slim from the outset, which begs the question of the rationale behind them.

\footnotetext{
${ }^{1}$ Although Qualified Majority Voting on tax issues is getting more attention. The Commission is currently developing a proposal in this direction (European Commission, 2019).
} 
This article will address this puzzle by arguing that the main purpose of the proposals was to pressure laggard states, most notably the US, in the OECD negotiations. A second objective was to ensure a degree of cohesiveness among EU members who wanted to unilaterally introduce defensive interim measures. From this perspective, the proposals can actually be evaluated successfully, despite not being implemented. This suggests that the unanimity requirement is less of a constraint on the EU's influence over tax governance than is often assumed (for example: Hakelberg, 2016a) A series of semi-structured elite interviews with EU and OECD officials provided empirical data for my arguments. I will be using insights from Kingdon's Multiple Streams Framework (Cairney \& Jones, 2016; Kingdon, 2014) (MSF) to structure the narrative and provide context-sensitive analysis by describing the dynamics of Kingdon's three streams at both the EU and OECD level. I will explain the EU Commission's proposal as cross-platform policy entrepreneurship: The use of power-broker capacities in one policy arena's streams to bias the options in one or more streams in another policy arena where its power broker capacities might be more limited or non-existent.

\section{Theoretical framework}

The multiple streams framework (MSF) (Kingdon, 2014) is a lens to analyze how ideas make their way onto the public policy agenda and ultimately become policies. The framework is built upon three assumptions, summarized by Ackrill, Kay \& Zahariadis (2013). First, 'Policy makers operate under significant and varying time constraints.' Policy makers cannot attend to all the potential problems they face and use heuristics to find solutions. This "bounded rationality" (Simon, 1978) leads them to prefer satisfactory outcomes to optimal ones. Second: 'solutions and problems are generated independently of each other'. Policy-making is not a linear process where a problem is identified, analyzed and then a rational solution is devised. Multiple solutions, with differing consequences for different stakeholders, compete. This means conflict is endemic to the political process (Ackrill et al., 2013). Third: 'Ambiguity permeates the process' Opaque actor preferences, vague organizational technology and fluid participation all bias the process in favor of those who generate information, control access to policy venues or synchronize timetables of multiple policy arenas (Ackrill et al., 2013).

Kingdon developed the approach in the context of US politics (Kingdon, 2014). Since then, the lens has been adapted to other countries or levels of governance. A meta-analysis by Jones et al. (2016) shows the framework has been applied to over 65 countries and eight times to the EU context.

The lens contains five key elements: Policy, Politics and problem streams - each with their own dynamics-; coupling and policy entrepreneurs. The problem stream refers to conditions that policymakers want addressed (Zahariadis, 2008). Policy-makers can only give attention to a limited number of problems at a given time. Cairney and Zahariadis (2016) identify three mechanisms for how problems become relevant in the problem stream: Variations in policy-relevant indicators (for example fluctuations in GDP), feedback to previous policy success/failure and focusing events (highly visible moments, such as crises).

The politics stream refers to the broader environment in which policy is made (Ackrill et al., 2013). For our purposes, we will use Zahariadis' (2008) operationalization of the EU politics stream. He identifies three factors: balance of the EU Council members' partisan affiliation, ideological balance of parties in Parliament and the European mood which refers to the climate of ideas fed by important policy-makers, opinion leaders and other politicos (Zahariadis, 2008). Since direct taxation 
is an exclusive member state competence, the Council presidency's mediation is especially important in tax matters. As taxation reform in the EU is embedded in a wider process instigated by the G20 and negotiated in the OECD, changing governments in key players of the G20/OECD also constitute a change in the tax politics stream.

The Policy stream is conceptualized as the existing solutions - independently generated - that are available to a given problem (Cairney \& Jones, 2016). Different experts and stakeholders may propose, debate and refine proposals that fit their values or interests. In taxation, NGOs, academics or business associations have long been debating different approaches. These float around in what Kingdon dubbed 'the policy primeval soup' (Kingdon, 2014, p. 134). Some ideas may float around for very long while never being implemented, while others rise very rapidly to the top of the agenda. Cairney and Zahariadis (2016) suggest that a solution will move forward more easily if it is perceived as technically feasible and if its values appeal to the major participants in a network (Vandenhende, 2017).

During rare moments, the three streams converge. These windows of opportunity can be triggered by changes in one or multiple streams (Ackrill et al., 2013). Triggers can be predictable, such as elections, or unpredictable. These fleeting moments interrupt the normal course of politics and give new issues a chance to be aired (Cairney \& Zahariadis, 2016). During these moments skillful policy entrepreneurs can couple the three streams: sell their favored policy as a solution to a topical problem to receptive policy-makers in charge. Zahariadis defines policy entrepreneurs as: "power brokers who manipulate problematic preferences and unclear technology and exploit the system's fluid participation rates to push forth their pet solutions. They do not decide on policies, policy-makers do. But they bias choice toward some options and away from others." (Zahariadis, 2008). The concept of policy entrepreneurism is essential to convey that agenda-setting is an actor-based process, even if context and structure cannot be divorced from it (Cairney \& Zahariadis, 2016).

The MSF emphasizes the temporal dimension of policy-making (Ackrill et al., 2013). Consider the different office terms of the EU Council members or the different policy cycles of the EU Commission (2014-2019) and the OECD digital tax process (2015-2020). Spohr (2016) proposes to integrate insights from historical institutionalism into the framework. He refers to path-dependency: the insight that existing institutions shape actors' interests and behavior (Hall \& Taylor, 1996). These are self-reinforcing because actors adapt to institutions by investing in them (Rixen, Viola, \& Zürn, 2016). This seems an important addition for an analysis of global tax policy given the resilient nature of the international tax regime. Spohr (2016) states that any proposal in the policy stream will likely be more successful when compatible with existing institutions, which corresponds to the technical feasibility criterion, and if it conforms with the values of policy makers, which can be shaped by existing institutions.

\section{The international tax regime and the problem stream of digital taxation}

Digital business models pose a challenge to the international principles on taxation in three broad ways: They can operate in a jurisdiction without a physical presence, they rely almost exclusively on intangible assets and the added value of end-user input is disputed.

Under the current model treaty, countries claim taxation rights on the profits of a multinational enterprise (MNE) because they are either the parent jurisdiction where the company is headquartered (residence state taxation), or because profits of the company originated within their jurisdiction, (source state taxation). To invoke source taxation, a company needs to have a fixed place of business - i.e. "permanent establishment"- in a jurisdiction (Genschel \& Schwarz, 2011). 
The size of each country's piece of a corporation's profits is determined by the transfer pricing regime. This is a set of rules for intra-company transactions, so that MNEs would not be able to declare profits in the jurisdiction with the lowest tax rate at will. The general principle is that intra-company transactions should follow the same conditions as if it concerned a third non-related party: the arm's length principle (Genschel \& Schwarz, 2011).

The OECD provides soft law templates for bilateral double tax agreements and transfer pricing guidelines. Nevertheless, this international consensus on taxation has become entrenched in a network of over 2800 (OECD, 2018a) such treaties. While there is no effective enforcement of this regime, it has proven very resilient and resistant to change (Rixen, 2011).

The arm's length principle, however, allows ample room for profit shifting to low-tax jurisdictions. MNE's use three broad mechanisms (Tørsløv, Wier, \& Zucman, 2018). Firstly, over- or understating transfer prices. Correctly determining a comparable arms' length price, especially for intellectual property and services, is not an exact science. Even within the scope of what is considered arms' length under the OECD's transfer pricing guidelines, there is leeway for tax planning. MNEs can also deliberately manipulate transfer prices and engage in transfer mispricing. Tax administrations can challenge the company if it suspects mispricing, and correct the price or engage in legal dispute. Second, MNEs can finance subsidiaries through loans, instead of equity, issued by affiliates in lowtax countries. A technique called thin capitalization. Contrary to dividends, remunerating equity; interests and remunerating debt are tax deductible. Third, MNEs place their intangible assets in lowtax countries, and charge royalties to affiliates using those assets (Tørsløv et al., 2018).

Digital business models share characteristics that exacerbate profit-shifting opportunities. First, the traditional nexus between source countries and companies, based on a permanent establishment, has become outdated (also acknowledged in BEPS). Technological innovations allow digital companies to offer goods and services without physical proximity, but with the same quality of service as if that proximity existed. A digital marketplace may offer next-day deliveries while not creating a taxable presence. This possibility of scale without mass means digital companies pay fewer taxes by running their operations from low-tax countries (OECD, 2018b).

A second issue is the unparalleled reliance on - hard-to-value - intangibles, such as algorithms, patents, trademarks... A digital marketplace can have algorithms in place, fed by user data, to track and predict demand which helps keep a leaner stock, decrease delivery time, target advertisements, and increase sales which all contribute to higher profits. These are easily placed in a subsidiary in a low tax country. Other parts of the company then have to pay royalties to that subsidiary. This is not unique to digital companies, but the dominance of intangibles in their value-chains exacerbates this problem. Such intangibles are very hard to value under the arms' length standard due to a lack of comparable market prices and their confidential nature (OECD, 2018b).

Another point of contention is the added value of user input in value creation. Digital companies collect user data and sell these to advertisers or use it to feed their algorithms. There is disagreement on whether user "clicks" actually generate taxable value. The Silicon Valley Tax Directors Groups argues that raw user data is not comparable to raw oil, and that value is only created by development and production of goods and services (Forohaar, 2017). Proponents argue that raw data has an inherent value and that it should be seen as a resource. The country that provides the resource should be able tax profits deriving from it (Forohaar, 2017).

\section{BEPS and digital taxation}


The apparently objective statement behind BEPS: "aligning taxation with economic substance and value creation", masks the inherent distributional conflict of coordinating taxes between states. Defining what constitutes value is much more a political process than an objective scientific exercise (Büttner \& Thiemann, 2017; Christians, 2018). Allocating parts of the tax base while avoiding double taxation is a coordination game with distributional conflicts (Radaelli, 1998; Rixen, 2011). States prefer a common standard to alleviate double taxation, hence the proliferation of double tax treaties. However, choosing which standard is conflictive as it can allocate a smaller or larger part of the tax base to either treaty partner (Radaelli, 1998).

Allocating standards mean different ways of determining an arm's length price, or non-arms' length ways of apportioning the tax base. Experts have endorsed a number of alternatives that include unitary taxation with formulary apportionment ${ }^{2}$ (UT+FA) (Avi-Yonah \& Tinhanga, 2017; Picciotto, 2017) or a destination-based cash flow tax (DBCFT) (Auerbach, Devereux, Keen, \& Vella, 2017) They endorse these alternatives because they are potentially more robust to illicit profit shifting or because they are conceptually closer to aligning value and taxation. The arms- length standard, however, has the advantage of pacification because it converts the larger distributional conflicts of taxation to a case-by-case application of the arm's length principle (Büttner \& Thiemann, 2017; Picciotto, 2015). These proposals, among others, all exist in the policy stream of corporate taxation.

Framing value alignment as the foremost problem in the problem stream narrowed the policy stream. While some civil society members suggested non-arms' length solutions to BEPS (Faccio et al., 2017; Piciotto et al., 2015), the BEPS outcomes firmly adhered to the arms'-length standard. The OECD had no mandate to explicitly address the division of the tax base between source and residence countries, nor to move away from the arm's length principle (personal interview, 2018). The only substantial change to allocation rules was enlarging the applicable scope of the profit-split method ${ }^{4}$ (OECD, 2017).

The problems identified with digital business models seem to require at least some modification to both nexus and allocation rules. A few are explored in the BEPS action 1 report (OECD, 2015a). The fact that digital businesses can avoid a traditional permanent establishment perhaps means that a new nexus with market countries should be established (the destination-principle). Solving profitshifting through intangibles might require amended transfer pricing principles. The report explores using the profit-split method more extensively as a starting point.

Ruling out a non-arms' length approach or the extension of allocation rules can be explained through the MSF IENS. Policy stream-wise, it would require extensive changes to the bilateral treaty network. The existing institutional context and the sunk cost states have invested in arm's length rules (Genschel \& Rixen, 2014) makes the technical feasibility of these changes less perceivable. It is also plausible be that policy-makers appreciate the arm's length principles' pacifying role (Rixen, 2011) and were not willing to open up distributional conflicts during BEPS (Büttner \& Thiemann, 2017), which invokes the value appeal argument.

\footnotetext{
${ }^{2}$ The tax base of a company is consolidated at the firm level, instead of the state level, and then divided among states through a formula usually based on a share of labor, assets and sales.

${ }^{3}$ A system that uses cash-flow instead of accounting profits as the base for corporate taxation. Taxes imports but exempts exports.

${ }^{4}$ A formulary/arm's-length hybrid method. It splits the profits resulting from a transaction in an arms'-length way by comparing the division of profits that independent enterprises would have agreed to when engaging in that transaction (Transfer Pricing Asia, 2018).
} 
In the political stream, heavy opposition came from the US. A state with immense bargaining power over international tax governance, due to the size of its internal market (Hakelberg, 2016; Lips, 2018). It hosts 63 of the world's top 100 digital MNE's parent companies and 39\% of all subsidiaries of digital companies (Unctad, 2017, p. 174). During BEPS, it opposed any proposal that ring-fenced digital companies (Lips, 2018). The US worried that other countries were trying to collect more taxes at their expense (Stack, quoted in Martin, 2016).

This opposition seemed to have paid off as the discussions were moved to the task force on digital economy who were expected to produce a new report in 2020 (OECD, 2015a). Several others, including the EU, were unhappy with this outcome and began considering interim defensive measures.

\section{Post BEPS developments in digital taxation}

\section{The EU arena}

Tax avoidance by MNEs was highly visible in the problem stream in the EU for most of the Juncker Commission's term (2014-19) due to three mechanisms: framing tax as essential for the internal market's functioning, tax scandals as focusing events, and a broader sentiment of anti-EU populism. In 2015, the Commission released its five-point action plan on corporate taxation (European Commission, 2015). The report framed taxation as imperative for the functioning of the single market. However, apart from the reintroduction of the common consolidated corporate tax base (CCCTB) (see below), the document itself is relatively vague on specific actions.

Broad coverage of tax scandals at well-timed intervals instigated the EU member leaders to come up with tangible actions. Some were the result of outside leaks. Most notably the International Consortium of Independent Journalist (ICIJ) who released the heavily mediatized Luxleaks (2014), on secretive Advance Pricing Agreements in Luxembourg, and the Paradise Papers (2017) on offshore tax avoidance.

Other mediatized events were the doing of the Commission itself. These were the state aid cases. Remarkably, the Commission used its authority on competition to argue that certain cases of special tax treatments by member states were in fact unfair state aid. The Commission then ordered to either recover due taxes or face a hefty fine. These cases involved companies as Ikea, Fiat, Amazon and Apple amongst others (European Commission, 2018d). The cases were also exemplary what states fear will happen when OECD agreement on digital taxation fails: uncoordinated actions by states to protect revenues. Reactions in the US were harsh and revealed the perception of an EU cash grab (US Department of the Treasury, 2016).

Regarding the policy stream, the Commission has on two occasions proposed fundamental changes to the international corporate taxation. The 2016 CCCTB relaunch proposition runs perpendicular to the OECD transfer pricing system. As a two-step approach, it would first define a common corporate tax base in the EU. Then the tax base would be consolidated at the EU level, with cross-border offset of losses, and apportioned by a formula based on equal weighting of sales, labor and assets. This would introduce unitary taxation in the EU for multinationals with a revenue over 750 million euros (European Commission, 2016).

The Commission then introduced the digital tax proposals in March 2018: an interim digital services tax (DST) of 3\% on revenue derived from certain digital transactions (European Commission, 2018b) and a long-term proposal for a significant economic presence (European Commission, 2018a). 
Profit allocation would work according to arms' length principles or in combination with the CC(C)TB as well (personal interview, 2018).

The proposals were criticized, however. The DST is levied on revenue which critics argue is not an adequate proxy for value creation, limiting its value appeal in the policy stream. Critics also mentioned that introducing a significant economic presence would require renegotiating all the EU members' tax treaties with third countries. If the US is opposed to the significant economic presence concept, it is unlikely it would renegotiate its tax treaties without OECD consensus.

The Commission should have anticipated that its plans were improbable without third country support, which reaffirms the suggestion that they were intended to influence the OECD process. Two interviews at different EU institutions confirm that one of the main functions of the DST proposal is to pressure laggard states at the OECD (personal interviews, 2018). Since the long-term proposal hasn't been discussed in the Council, from here on, the focus will be on the DST.

The political stream in the EU consists of the balance of the EU Council member, ideological balance of parties in Parliament and the European mood (see supra). The European parliament generally was supportive of the Commission's tax agenda and voted in favor of both the CCCTB and the significant economic presence proposal (EU Parliament, 2018). The general mood, although hard to qualify, in Europe can be described as favorable to international tax reforms. Domestic pressures on EU governments to do be 'seen doing something' at multinational tax avoidance is significant: "member states don't want to keep telling their people that no contribution is made by GAFA" (Google, Amazon, Facebook, Apple) (Personal interview, 2018).

Tax matters in the EU Council require unanimity. Therefore, the Council presidency and its capability to forge a consensus are as important as the balance of governments' ideological preferences. The trio of EU countries that held the EU presidency during the relevant periods for the DST (September '17 - December '18) are Estonia, Bulgaria and Austria ${ }^{5}$. The Commission's first communication was released at the start of the Estonian presidency. At an informal ECOFIN Council the following October, France along with Italy, Spain and Germany and 6 other Council members called for the Commission to move forward with its plans (personal interview, 2018).

When the Commission eventually released its proposals in March 2018, camps immediately formed. France is amongst the staunchest proponents. President Macron built a 'PR-machine' (personal interview, 2018) that helped build momentum. Ireland, as a top location where companies place intangible property (Brauner, 2014), immediately spoke out against; as did Luxembourg and the Netherlands (Plucinska, Vinocur, \& Smith-Meyer, 2018; Times, 2018).

Germany was ambiguous towards the DST. While it was in favor initially, reports show Germany was on the fence during the ECOFIN meeting following the release (Reuters 2018). One source of this reluctance is believed to be the tariff threats the US made at the time (Plucinska et al., 2018).

The interim DST was discussed under the Austrian Council Presidency in the second half of 2018. The presidency first introduced a sunset clause, so that the DST would end once an OECD agreement was reached. This links the DST to the OECD policy and political streams and turns it into a more explicit pressure mechanism. This was unfruitful. At the ECOFIN in November 2018, three countries officially spoke out against the DST proposal: Ireland, Finland and Sweden (Khan, 2018). France and Germany, on the outset of the December ECOFIN, proposed a compromise: a severely narrowed down DST that would only include online advertisement sales turnover. The proposal now included a sunrise clause, so that it would only come in force if no OECD agreement was reached

${ }^{5}$ Romania takes the Presidency in January 2019 
(France \& Germany, 2018). One of the reasons France was willing to give in this much, were the European elections in May 2019 (Khan \& Brunsden, 2018). These elections are a focusing event, making France, and others, aim for a satisfactory, rather than an optimum, solution to show their electorates. The final vote was due in March 2019, where it failed to reach agreement. The digital tax proposals were put on hold and deferred to the OECD (Council of the european union, 2019).

Member states can still impose a DST on their own (France \& Germany, 2018). Italy for example has already imposed a tax on advertisement (EY, 2018), Spain too will introduce a DST, based closely on the EU proposal (Gonzàlez, 2018), as will the United Kingdom (Turner \& Ali, 2018) and France (Keohane, 2018). Countries usually do not like to take unilateral action on taxation issues, for fear of company relocations. However, digital companies cannot use this threat of relocation if they already avoid having a permanent establishment in most jurisdictions. Additionally, a DST targets the least mobile part of an MNE's value chain: sales. Companies cannot relocate their customer base.

The EU Commission's directives were political in nature. One interviewee described them as: “going against some member states' interests, and beyond its role as technical advisor to the political Council" (personal interview, 2018). It would be unfair however to rule the proposal a failure. Interviews within the EU bodies revealed that the Commission had two objectives: avoid fragmentation on interim digital tax measures for single market reasons (European Commission, 2018b), and provide an impulse to the OECD negotiations (personal interviews, 2018). The Commission appears to have succeeded in the first objective. All proposed unilateral measures follow the blueprint of the DST proposal. The second objective will be discussed in the next section.

\section{The OECD arena}

21 of the 28 EU countries are OECD members and the EU has a special participant status and a permanent delegation. The dynamics of the EU arena thus are naturally reflected in the OECD's task force on digital economy (TFDE)). In this problem stream, the urgency of the digital tax problem is exacerbated by looming threats of unilateralism.

As to the policy stream, TFDE members took several positions on how to best tackle the issues of the digital economy, from digital-specific reforms to a more market jurisdiction-based approach (personal interview, 2018, OECD 2018b). Replacement of the arm's length standard is still inconceivable in the OECD's policy stream. This is in line with the MSF's predictions on value acceptance and technical feasibility. Since the OECD is the technical overseer of the transfer pricing regime, its policy advisors should hold the norm in high regard: they produce most of the guidance and technical principles. However, one OECD interviewee remarked that the OECD's position merely reflect the preferences of its member states (personal interview, 2018). Institutional path-dependency also plays a role as OECD policy is entrenched in a network of bilateral tax treaties. This makes introducing alterations to tax principles harder as these treaties have to be renegotiated one by one.

A key change is post-BEPS in the political stream is the US' stance on international taxation. The Trump administration overhauled its corporate tax system with the Tax Cuts and Jobs Act (TCJA) in 2017. Besides lowering the tax rate from $35 \%$ to $21 \%$, the US reduced the deferral provisions that allowed US companies to let their foreign profits go untaxed until repatriation. Other provisions were the Global Intangible Low-Tax Income (GILTI), a minimum tax on domestic companies foreign lowtaxed intangible income, and the Base Erosion Anti-Abuse Tax (BEAT), an alternative minimum tax on companies' US income (Heineman \& Spengel, 2018). The latter signaled a profound discontent 
with the outcomes of the arms' length approach and BEPS outcomes on US revenues. OECD director Saint-Amans dubbed BEAT 'A vote of none (sic) confidence against the arms' length principle' (Taxnote Talk podcasts, 2018).

It is too early to evaluate the global implications of the US tax (personal interviews, 2018). However, introducing anti-abuse reforms that go beyond the BEPS outcomes, arguing that they are necessary to protect US tax revenues, makes it harder for the US to oppose others doing the same. Even if this hurts US MNEs' interests. This makes it more important for the US to streamline a coordinated response to the digital tax question, even if their position is that reform is not necessary.

Countries in the political stream who contemplated implementing defensive measures- not just European countries but also for example India (Bulusu, 2018) - in effect reframed the problem of digital taxation as a threat of uncoordinated unilateral measures, which even states who prefer the status quo should want to avoid (see (Radaelli, 1998). That this framing at least seemed plausible can be empirically confirmed by a few observations. First is the OECD's attempts to streamline unilateral interim measures by suggesting ground rules in the 2018 interim report (OECD, 2018b). Secondly, the US Senate sent an official letter to the EU Council and Commission presidents, pleading to abandon the DST (Hatch \& Wyden, 2018). Thirdly, at the timing of the December ECOFIN Council, Business at OECD, an affiliated advisory committee, released a letter urging countries not to undertake unilateral or regional action on digital taxation (BIAC, 2018). Even if laggard states strategically thought that the DST would never pass the unanimity requirement, ambiguity concerning EU states' willingness to unilaterally introduce a DST should have been too uncertain to ignore. This was confirmed when several large EU states committed to introducing one.

This reframing in the problem stream appears to have paid off. The US effectively committed itself to finding a solution: a position change so significant, the OECD explicitly names it in its report to the G20 leaders: "Following the US tax reform, the United States has in particular agreed to engage in the search of a global solution which would address further challenges." (OECD, 2018c). Although this report attributes the position change to the US tax reform, neither the 2018 interim report (OECD, 2018b), nor interviews undertaken in May-June 2018 suggest this position change already happened. While we cannot unambiguously attribute the change to the pressure of the DST based on this available evidence; at least temporally, the US position change happened after this reframing. US Treasury Secretary Mnuchin also made reference to the urgency created by the EU's and France's proposals at the 2019 G20 meeting in Japan (Robert, 2019).

Another link between the Commission's proposals, and OECD's political stream is that they made EU states opposed to the proposals rhetorically committed to finding a global OECD solution. Ireland, for example, stated it favored an OECD solution as part of its principled opposition to the EU's proposals, so its commitment on contributing to that solution should have increased as a result.

In the policy-stream, a compromise seems to crystalize. A two-pillar approach that consists of (a) a pillar exploring nexus solutions to re-allocate profits to the market jurisdiction and (b) an antierosion pillar exploring a global minimum tax on MNE's controlled foreign income, similar to GILTI but on a per-country basis; and a tax on base-eroding payments similar to BEAT (Becker \& Englisch, 2019; OECD, 2019).

These proposals have advantages in terms of value acceptance, increasing their chances of adoption. They don't ring-fence digital companies, which means it lacks the anti-GAFA framing of the EU proposals. Since it follows the US model, the US cannot really object. And since the TCJA is compatible with existing tax treaties and the mechanism closely resemble existing controlled foreign 
company (CFC) rules, the proposals also show technical feasibility. Global minimum taxes could also alleviate public perception that the digital companies are paying too little taxes, since effectively a global floor would be installed. As these are aimed at low-tax havens, they don't strain the tax relations between higher-tax countries (Becker \& Englisch, 2019).

At the time of writing (mid-2019), no outcome has been reached yet but the optimism in the OECD is tangible. The OECD report to the G20 explicitly mentions the potential for a solution, (OECD, 2018c). Furthermore, the finance ministers of France and the US jointly confirmed a commitment at reaching a solution at the OECD (Mallet \& Toplensky, 2019).

The EU Commission's proposals effectively changed the dynamic of the OECD political stream, by driving up political tensions between laggards and proponents of a digital tax-specific reform, and problem stream, through the threat of uncoordinated unilateral measures. Using its prerogatives to propose a very politicized proposal into the EU policy stream, played out as a form of policy entrepreneurism across platforms in the OECD arena. A new policy proposal in the OECD policy stream, based around the US TCJA, then was the final element to open a preliminary reform window on digital taxation.

\section{Conclusion}

This article examined the rationale behind, and the agenda-setting effects of, the EU Commission's digital tax proposals, especially the interim DST. These proposals were puzzling because they seemed to challenge the primacy of the OECD as the leading forum on tax reform, because of the US tax grab framing, and because the unanimity requirement meant chances of implementation were slim to non-existent. Since the proposals did not pass in the Council, it would be tempting to see the proposals as a failed attempt at solving the taxation-related problems of the digitalized economy in the EU single market. When judged against the original intents of the proposal: providing a coherent framework for defensive measures and increase pressure on laggard OECD states to move towards a negotiated solution, the outcomes seem more positive.

Drawing on insights from Kingdon's Multiple Streams Framework allowed me to trace the impact of the proposals on policy proposals, problem framing and political divisions in both the EU and OECD. The Commission proposals served as a form off cross-platform policy entrepreneurship, influencing not only the EU's streams, but the OECD's as well.

Public salience of tax avoidance and artificial profit shifting has been growing in the EU due to exogenous (mediatized tax leaks) and endogenous (state aid cases) events. The issue was relevant in the problem stream for almost the entire duration of the Juncker Commission, aided by the looming threat of anti-EU populism. However the unanimity requirement in the political stream blocked the DST's chances of implementation. What the Commission did achieve though, is providing coherency to unilateral defensive measures taken by EU member states. All member states that intend to introduce such measures seem to follow the Commission's DST blueprint.

In the OECD arena, the digital tax conundrum was unresolved in the BEPS project. In the political stream, several countries, most notably the US, were opposed to any solution that ring-fenced digital business models. The Commission proposals, among others such as India's, drove up the tensions in the political stream between countries wanting a swift solution and laggard countries. By taking up leadership within the EU, the Commission threatened to have 21 OECD countries introduce a DST. Even though others knew the chances of adoption were slim, several large EU countries 
expressed intent to introduce them unilaterally and the proposals created a 9 month period of ambiguousness. This reframed the digital tax issue in the OECD problem stream to the threat of uncoordinated defensive unilateral measures. Meanwhile the completion of the US tax reform changed the position of the US on digital tax reform. A policy proposal resembling the global minimum tax features of the TCJA combined with a proposal to tax intangible income in the market jurisdiction, apparently aligned the three streams into a window of opportunity for digital tax reform.

It is important to note that this study does not suggest the Commission proposals are solely responsible for creating an opportunity window for digital tax reform, or that without the EU's proposals a window would not eventually open. Other factors such as the TCJA obviously interacted with the Commission proposals. The scope of this article is an outcome explanation of a case study of the Commission proposals.

What does this teach us about the broader study of tax governance? The fact that the OECD solution probably will closely resemble the TCJA seems to confirm Eccleston's statement 'that since the 1960s the broad contours of international tax cooperation have been defined by changing US policy preferences' (Eccleston, 2012, p. 134). This would only be partially correct, since the US was and still is not a demanding party for digital tax reforms; whether they resemble US legislation or not. On the contrary, the digital tax saga shows the increased assertiveness of the EU Commission towards the US on tax matters. The EU's market power is large enough to grant it material power over the outcome of tax governance (Lips, 2018), if it can overcome the unanimity requirement (Hakelberg, 2016). While this did not happen, the ambiguousness the proposals created seemed enough to increase the conflict and catalyze change in the stable system of tax governance. This shows the EU Commission can instrumentalize this market power towards external actors through strategic leadership, creating temporal lag and cross-platform policy entrepreneurship. 


\section{References}

Ackrill, R., Kay, A., \& Zahariadis, N. (2013). Ambiguity , multiple streams , and EU policy Ambiguity , multiple streams , and EU policy. Journal of European Public Policy, 20(6), 871-887.

http://doi.org/10.1080/13501763.2013.781824

Auerbach, A., Devereux, M. P., Keen, M., \& Vella, J. (2017). Destination-Based Cash Flow Taxation, (January). Retrieved from

http://www.sbs.ox.ac.uk/sites/default/files/Business_Taxation/Docs/Publications/Working_Papers/Series _17/WP1701b.pdf

Avi-Yonah, R., \& Tinhanga, Z. P. (2017). formulary apportionment and international tax rules. In S. Picciotto (Ed.), Taxing Multinational Enterprises as Unitary Firms (pp. 67-75). ICTD.

Becker, J., \& Englisch, J. (2017). A European Perspective on the US Plans for a Destination Based Cash Flow Tax. Oxford University Centre for Business Taxation, (February).

Becker, J., \& Englisch, J. (2019). The German proposal for an effective minimum tax on multinational's profits. Retrieved January 25, 2019, from https://www.taxjustice.net/2019/01/15/the-german-proposalfor-an-effective-minimum-tax-on-multinationals-profits/

BIAC. (2018). Business urges governments to continue multilateral approach to digital tax. Retrieved from $11 / 12 / 2018$

Brauner, Y. (2014). What the BEPS? Florida Tax Review (Vol. 16). Retrieved from http://ssrn.com/abstract=2408034

Bulusu, S. (2018). India Will Forge Ahead on Digital Tax-Alone if Necessary: Tax Chief. Retrieved December 11, 2018, from https://www.bna.com/india-forge-ahead-n57982091614/

Büttner, T., \& Thiemann, M. (2017). Breaking Regime Stability? The Politicization of Expertise in the $\mathrm{OECD} / \mathrm{G} 20$ Process on BEPS and the Potential Transformation of International Taxation. Accounting, Economics, and Law: A Convivium, 7(1). http://doi.org/10.1515/ael-2016-0069

Cairney, P., \& Jones, M. D. (2016). Kingdon's Multiple Streams Approach: What Is the Empirical Impact of this Universal Theory? Policy Studies Journal, 44(1), 37-58. http://doi.org/10.1111/psj.12111

Cairney, P., \& Zahariadis, N. (2016). Multiple streams analysis. In N. Zahariadis (Ed.), Handbook of Public Policy Agenda Setting (pp. 87-105). Cheltenham: Edward Elgar.

Christians, A. (2018). Taxing according to value creation. Tax Notes.

Council of the european union. (2019). Digital taxation. Retrieved June 1, 2019, from https://www.consilium.europa.eu/en/policies/digital-taxation/

Eccleston, R. (2012). The Dynamics of Global Economic Governance. The financial crisis, the OECD and the politics of international tax cooperation. Cheltenham: Edward Elgar Publishing.

EU Parliament. (2018). MEPs approve new EU corporate tax plan which embraces "digital presence." Retrieved July 24, 2018, from http://www.europarl.europa.eu/news/en/pressroom/20180309IPR99422/meps-approve-new-eu-corporate-tax-plan-which-embraces-digital-presence

European Commission. (2015). A Fair and Efficient Corporate Tax System in the European Union: 5 Key Areas for Action. Communication from the Commission to the European Parliament and the Council.

European Commission. (2016). Proposal for a council directive on a Common Consolidated Corporate Tax 


\section{Base (CCCTB).}

European Commission. (2018a). Proposal for a council directive laying down rules relating to the corporate taxation of a significant digital presence, 2018/0072 (CNS).

European Commission. (2018b). Proposal for a council directive on the common system of a digital services tax on revenues resulting form the provision of certain digital services, 2018/0073 (CNS).

European Commission. (2018c). Questions and Answers on a Fair and Efficient Tax System in the EU for the Digital Single Market. Retrieved July 1, 2019, from http://europa.eu/rapid/press-release_MEMO-182141 en.htm

European Commission. (2018d). Tax rulings. Retrieved from http://ec.europa.eu/competition/state_aid/tax_rulings/index_en.html

European Commission. (2019). Decision making on EU Tax Policy. Retrieved June 2, 2019, from https://ec.europa.eu/taxation_customs/taxation/decision-making-eu-tax-policy_en

EY. (2018). Digital Tax Development Map. Retrieved July 24, 2018, from https://www.ey.com/gl/en/services/tax/ey-digital-tax-development-map

Faccio, T., Picciotto, S., Brockmeyer, A., Clausing, K., Durst, M., Fleming, C., ... Nerudová, D. (2017). Alternatives to the Separate Entity / Arm 's Length Principle, ICRIT.

Forohaar, R. (2017). Data is the new oil and digital taxation may be the reform the US really needs. Retrieved January 11, 2018, from http://www.afr.com/opinion/columnists/data-is-the-new-oil-and-digital-taxationmight-be-the-reform-the-us-really-needs-20171112-gzjydp

Forstater, M., \& Christensen, R. (2017). New Players, New Game. The role of the public and political debate in the development of action on international tax issues. European Tax Policy Research Paper.

France, \& Germany. (2018). Franco-German joint declaration on the taxation of digital companies and minimum taxation We. Retrieved from https://www.consilium.europa.eu/media/37276/fr-de-jointdeclaration-on-the-taxation-of-digital-companies-final.pdf

Genschel, P., \& Rixen, T. (2014). Settling and Unsettling the Transnational Legal Order of International Taxation, 1-24. Retrieved from http://www.eui.eu/Documents/DepartmentsCentres/SPS/Profiles/Genschel/SPSGenschelRixen2014.pdf

Genschel, P., \& Schwarz, P. (2011). Tax Competition: A Literature Review. Socio-Economic Review, 9(2), 339-370. http://doi.org/10.1093/ser/mwr004

Gonzàlez, J. S. (2018). Spanish Finance Ministry to introduce digital tax for firms like Airbnb and Uber. Retrieved October 12, 2018, from https://elpais.com/elpais/2018/10/05/inenglish/1538741424_819871.html

Hakelberg, L. (2016). Coercion in international tax cooperation: identifying the prerequisites for sanction threats by a great power. Review of International Political Economy, 2290(January), 1-31. http://doi.org/10.1080/09692290.2015.1127269

Hall, P. A., \& Taylor, R. C. R. (1996). Political Science and the Three New Institutionalisms. Political Studies, 44(5), 936-957. http://doi.org/10.1111/j.1467-9248.1996.tb00343.x

Hatch, O., \& Wyden, R. (2018). US Senate Committee on Finance, Letter to the EU. Retrieved from https://www.finance.senate.gov/imo/media/doc/2018-10-18 OGH RW to Juncker Tusk.pdf

Heineman, F., \& Spengel, C. (2018). Analysis of US Corporate Tax Reform Proposals and their Effects for 


\section{Europe and Germany.}

Jones, M. D., Peterson, H. L., Pierce, J. J., Herweg, N., Bernal, A., Lamberta Raney, H., \& Zahariadis, N. (2016). A River Runs Through It: A Multiple Streams Meta-Review. Policy Studies Journal, 44(1), 1336. http://doi.org/10.1111/psj.12115

Keohane, D. (2018). France accelerates plans for its own digital tax. Retrieved January 22, 2018, from https://www.ft.com/content/a4881362-0216-11e9-9d01-cd4d49afbbe3

Khan, M. (2018, November 6). EU's tech tax is going nowhere fast. Financial Times. Retrieved from https://www.ft.com/content/cdbb6ce8-e16e-11e8-8e70-5e22a430c1ad

Khan, M., \& Brunsden, J. (2018). France and Germany abandon plans for EU digital tax. Retrieved December 12, 2018, from https://www.ft.com/content/fc7330d4-f730-11e8-af46-2022a0b02a6c

Kingdon, J. (2014). Agendas, alternatives and public policies. second edition. Essex: Pearson.

Lips, W. (2018). Great powers in global tax governance : a comparison of the US role in the CRS and BEPS. Globalizations, 1-16. http://doi.org/10.1080/14747731.2018.1496558

Mallet, V., \& Toplensky, R. (2019). US and France accelerate plans to make global tech groups pay tax. Retrieved March 1, 2019, from https://www.ft.com/content/2bf5859e-3b71-11e9-b72b-2c7f526ca5d0

Martin, J. (2016). Countries targeted US companies in BEPS project to increase tax revenue, US Treasury official charges. Retrieved December 6, 2016, from http://mnetax.com/countries-targeted-us-companiesbeps-increase-tax-revenue-treasury-stack-15131-15131

OECD. (2015a). Action 1: Final Report Addressing the Tax Challenges of the Digital Economy. Base Erosion and Profit Shifting Project. http://doi.org/http://dx.doi.org.10.1787/9789264202719-en

OECD. (2015b). OECD/G20 Base Erosion and Profit Shifting Project. Executive Summaries 2015 Final Reports. http://doi.org/10.1016/S0090-2616(15)00007-8

OECD. (2017). BEPS Action 8-10 Revised Guidance on Profit Splits - Public Discussion Draft.

OECD. (2018a). Exchange of information portal. Retrieved July 12, 2018, from http://www.eoitax.org/\#default

OECD. (2018b). OECD/G20 Base Erosion and Profit Shifting Project Tax Challenges Arising from Digitalisation - Interim Report 2018. http://doi.org/10.1787/9789264293083-en

OECD. (2018c). Secretary-General Report To the G20 Leaders. Buenos Aires.

OECD. (2019). Addressing the Tax Challenges of the Digitalisation of the Economy. Public Consultation Document. Retrieved from http://www.oecd.org/tax/beps/public-consultation-document-addressing-thetax-challenges-of-the-digitalisation-of-the-economy.pdf

Picciotto, S. (2015). Indeterminacy, Complexity, Technocracy and the Reform of International Corporate Taxation. Social and Legal Studies, 24(2), 165-184. http://doi.org/10.1177/0964663915572942

Picciotto, S. (2017). Taxing Multinational Enterprises as Unitary Firms. ICTD Working Paper 53. Brighton: ICTD. Retrieved from http://taxwatch.org.au/wp-content/uploads/2016/06/Taxing-multinationalenterprises-as-unitary-firms.pdf

Piciotto, S., Dahlbeck, A., Gambini, A., Grondona, V., Kadet, J., Neuwirth, M., ... Weyzig, F. (2015). Overall Evaluation of the G20/OECD Base Erosion and Profit Shifting (BEPS) Project. 
Plucinska, J., Vinocur, N., \& Smith-Meyer, B. (2018). Europe's digital tax map: Where countries stand. Retrieved April 16, 2018, from https://www.politico.eu/article/europe-digital-tax-map-where-countriesstand-analysis-deep-divisions/

Radaelli, C. M. (1998). Game theory and institutional entrepreneurship: Transfer pricing and the search for coordination in international tax policy. Policy Studies Journal, 26(4), 603-619. http://doi.org/DOI 10.1111/j.1541-0072.1998.tb01935.x

Reuters. (2018). Nordic countries oppose EU plans for digital tax on firms' turnover. Retrieved July 24, 2018, from https://www.reuters.com/article/us-eu-digital-tax/nordic-countries-oppose-eu-plans-for-digital-taxon-firms-turnover-idUSKCN1IW337

Rixen, T. (2011). From Double Tax Avoidance to Tax Competition: Explaining the Institutional Trajectory of International Tax Governance. Review of International Political Economy, 18(2), 197-227. http://doi.org/10.2139/ssrn.1589132

Rixen, T., Viola, L. A., \& Zürn, M. (2016). Historical institutionalism and international relations. Oxford: Oxford University Press.

Robert, H. (2019). Digital giants face tax setback after G20 agreement. Retrieved June 2, 2019, from https://www.ft.com/content/f00d2f70-8a6f-11e9-a1c1-51bf8f989972

Simon, H. a. (1978). Rational Decision-Making in Business Organizations. In Nobel Memorial Lecture, 8 December, 1978. http://doi.org/10.2307/1808698

Spohr, F. (2016). Explaining Path Dependency and Deviation by Combining Multiple Streams Framework and Historical Institutionalism: A Comparative Analysis of German and Swedish Labor Market Policies. Journal of Comparative Policy Analysis: Research and Practice, 18(3), 257-272. http://doi.org/10.1080/13876988.2015.1122210

Taxnote Talk podcasts. (2018). Tax Challenges of the Digital Economy. Retrieved from https://www.taxnotes.com/tax-notes-talk

Times, I. (2018). Ireland not alone in opposing EU digital tax plan. Retrieved July 24, 2018, from https://www.irishtimes.com/business/economy/ireland-not-alone-in-opposing-eu-digital-tax-plan1.3429999

Tørsløv, T. R., Wier, L. S., \& Zucman, G. (2018). The missing profits of nations. NBER Working Paper Series, (27401).

Transfer Pricing Asia. (2018). The Profit Split Method With Example. Retrieved July 13, 2018, from https://ransferpricingasia.com/2017/04/11/profit-split-method-with-example/

Turner, G., \& Ali, H. (2018). U.K. Targets Tech Giants With a Digital Services Tax in 2020. Retrieved November 6, 2018, from https://www.bloomberg.com/news/articles/2018-10-29/u-k-targets-tech-giantswith-a-digital-services-tax-in-2020

Unctad. (2017). World Investment Report 2017 - Investment and the digital economy.

US Department of the Treasury. (2016). The European Commission's Recent State Aid Investigations of Transfer Pricing Rulings. White Paper.

Vandenhende, S. (2017). The Eu and Tax Avoidance by Multinational Corporation. A Multiple Streams Analysis of the Proposal for a CCCTB. Ugent.

Zahariadis, N. (2008). Ambiguity and choice in European public policy Ambiguity and choice in European public policy. Journal of European Public Policy, 15(4), 514-530. 
http://doi.org/10.1080/13501760801996717 